\title{
Reinventing Roman Ethnicity in High and Late Medieval Byzantium
}

\author{
Yannis Stouraitis*
}

This paper seeks to position the Byzantine paradigm within the broader discussion of identity, ethnicity and nationhood before Modernity. In about the last decade, there has been a revived interest in research into collective identity in Byzantine society, with a number of new publications providing various arguments about the ethno-cultural or national character of Byzantine Romanness as well as its relationship to Hellenic identity. Contrary to an evident tendency in research thus far to relate Byzantine, i.e. medieval Roman, identity to a dominant essence - be it ethnic Hellenism, Chalcedonian orthodoxy or Roman republicanism - the approach adopted here aims to divert attention to the various contents and the changing forms of Byzantine Romanness as well as to its function as a dominant mode of collective identification in the medieval Empire of Constantinople. The main thesis of the paper is that the development of Roman identity in the East after the turning point of the seventh century and up to the final sack of Constantinople by the Ottomans in 1453 needs to be examined as one of the most fascinating cases of transformation of a pre-modern social order's collective identity discourse, one which culminated in an extensive reconstruction of the narrative of the community's historical origins by the educated élite. Last but not least, the problematization of the function of Romanness as an ethnicity in the Byzantine case offers an interesting example for comparison in regards to the debated role of ethnicity as a factor of political loyalty in the pre-modern era.

\section{Keywords: Byzantine identity; Romanness; Hellenism; ethnicity}

In roughly the last decade, a number of new publications have revisited the question of collective identity in Byzantium. ${ }^{1}$ This revived research interest testifies to a shift of focus. Departing from an established consensus in the field, which does not question the self-designation of the so-called Byzantines as Rhomaioi (Romans), almost all of these recent publications focus on the development of the form and content of Byzantine Romanness. Here, two basic approaches can be discerned: the first points to the configuration of a dominant Roman ethnicity within the framework of the medieval eastern Roman imperial community - at the latest from the twelfth century onwards ${ }^{2}$; the second suggests that Romanness had already taken the form of a civic or state-framed national identity in the late-Roman Empire and that the medieval Rhomaiōn politeia was a nation-state and not an empire. ${ }^{3}$

* Correspondence details: Yannis Stouraitis, Department of Byzantine and Modern Greek Studies, University of Vienna, Postgasse 7/1/3, 1010 Vienna, Austria. Email: ioannis.stouraitis@univie.ac.at.

1 Beaton, Antique Nation; Kaldellis, Hellenism; idem, From Rome to New Rome; Rapp, Hellenic Identity; Page, Being Byzantine; Koder, Byzantium as Seen by Itself; Malatras, Making of an Ethnic Group; Stouraitis, Roman Identity;

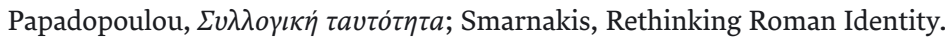

2 Page, Being Byzantine, 72 f.; Malatras, Making of an Ethnic Group, passim; Stouraitis, Roman Identity in Byzantium, $206 \mathrm{f}$.

3 Kaldellis, Hellenism, 42-119; idem, From Rome to New Rome, passim. 
Regarding pre-modern group-identity, the use of terms and categories, such as city-state, ethnic group, nation, empire or nation-state, is more often than not a question of a historian's taste and choice. Modern historians can be roughly distinguished between those that choose to employ terms and categories in a manner intended to lump together different phenomena and those that do it in order to distinguish between them. One way or the other, the applicability of analytical concepts (such as nationhood, ethnicity etc.) as means that help us to clarify certain complexities and to think about historical phenomena is interrelated with their ability to provide a coherent interpretation of the evidence of our sources. ${ }^{4}$

The dominant theoretical paradigm, which defines nations and nation-states as recent historical phenomena related to the rise of nationalism in the context of the social conditions of Modernity, has come under sustained criticism since the 1990s, especially from the so-called ethnosymbolist approach ${ }^{5}$. This criticism has certainly offered useful corrections to what had become a stifling modernist orthodoxy, but one cannot help noticing that now the pendulum seems to be swinging a bit too far in the opposite direction. Once again it is très à la mode to speak of nations and nation-states in all eras and historical cases where state formation coincided with a dominant ethnic or cultural discourse. ${ }^{6}$ This trend is often complemented by a tendency to caricaturize the modernist thesis and to downplay how this has evolved since the influential works of Gellner, Hobsbawm and Anderson - and partly too in response to ethnosymbolist criticism. ${ }^{7}$

From an analytical point of view, the nation is defined as an imagined political community which is not only characterized by a congruence of cultural/ethnic and political boundaries, but also by the habitual mass identification of its members with the idea of the sovereign people as the principal unit of human solidarity and political legitimacy. This identification is the product of (so-called banal) nationalism as a dominant operative ideology that pervades national communities and reproduces their groupness on a daily basis. ${ }^{8}$ Nationhood as a political claim and not as an ethno-cultural fact marks the difference between the national community as a phenomenon of modernity and the pre-modern ethnic group as a non-stable and non-coherent collectivity of notional common kinship and selected cultural markers that need not circumscribe its members' political loyalty. ${ }^{9}$ Moreover, it distinguishes nation-states from pre-modern forms of state-framed communities such as kingdoms and empires with a dominant (élite) culture or ethnicity, and where the body politic was structured in a centripetal and hierarchical manner around the authority of the king or the emperor.

In the context of a comparative approach to identity, ethnicity and nationhood before Modernity, my intention in the current paper is to depart from such clear-cut definitions of nationhood and ethnicity as analytical categories in order to examine the development of

5 Smith, Nationalism and Modernism; idem, Ethno-Symbolism and Nationalism; cf. Ichijo and Uzelac, When is the Nation.

6 See the endorsement of Gat, Nations, by Smith, Book Review.

7 Malešević, Identity as Ideology, 109-153 (a critique of both Smith's and Gellner's theories about the nation); idem, »Divine Ethnies« and »Sacred Nations«, passim.

8 E.g. Brubaker, Rethinking Nationhood, 3-14; Billig, Banal Nationalism, esp. 37-59 and 93-127; Malešević, Identity as Ideology, 89-108; idem, Nation-States and Nationalisms, 1-88;

9 On ethnicity, see Jenkins, Rethinking Ethnicity, 3-16 and 77-89; Smith, National Identity, 19-25; Brubaker, Ethnicity without Groups, 1-87. 
Byzantine Romanness regarding: 1) continuities and discontinuities in the vision of imperial community; 2) political and cultural identifications, and the salience of a dominant Roman ethnicity in high-medieval Byzantium; 3) the relationship between dominant ethnicity and political loyalty; and 4) the reconstruction of the community's past in late-medieval Byzantium.

\section{Rome was humbled but did not fall}

In chapter 27 of his political treatise De administrando imperio, written in the mid-tenth century, Emperor Constantine VII (913-959) remarked that the imperium had crossed to Constantinople when Rome stopped being governed by an emperor - an allusion to late-fifth century developments. ${ }^{10}$ The late-twelfth century history of John Kinnamos presented a fullblown version of this Byzantine claim: the title of empire had disappeared in Rome, since the attributes of power had passed after Augustulus to Odoacer and then to Theoderic, for which reason the current rulers in the West had no rightful claim to the title of Roman Emperor, but instead they and the pope had to accept that the throne of the empire in Byzantium was the throne of Rome. ${ }^{11}$ From the view-point of the Byzantine élite, the major event of translatio imperii was a historical process that began with the transfer of the imperial capital from Rome to Constantinople by Constantine $\mathrm{I}^{12}$ and was concluded with the dethronement of the last emperor of Rome. This historical scheme was conducive to the Byzantine vision of an unbroken continuity of Roman imperial community in the East: since the late-fifth century there had remained a single city-state and a single emperor as the sole legitimate bearers of Roman imperial culture in the Oecumene, whose limits of authority circumscribed the boundaries of the Roman political-territorial community.

The central role of the city-state of New Rome and its emperor in determining the form of the medieval East Roman community as an imperial political order is currently a matter of debate. ${ }^{13}$ The thesis that Byzantium was not an empire but a nation-state was recently elaborated through the argument that the medieval Rhomaion politeia was a monarchical republic (res publica) whose operative political ideology and political practice were defined by popular sovereignty. ${ }^{14}$ This argument has been criticized for downplaying the political structures and the social and material conditions into which the reproduction of Roman republican tropes in the political discourse of the Byzantine élite was embedded, as well as for taking rebellions against the emperors as evidence of popular sovereignty. ${ }^{15}$ Besides this criticism, a closer look at the discourse of late Roman and Byzantine sources demonstrates that the Byzantine conception of the Rhomaion politeia had very little to do with the nation as an imagined political community with culturally and territorially finite boundaries. ${ }^{16}$

1 Kinnamos, Epitome, ed. Meinecke, 218-220.

12 Cf. the testimony of Liutprand of Cremona, Legatio, 51, ed. Chiesa, 209, 830-835.

13 On the nation-state thesis, see n. 3 above. Contra, Stouraitis, Roman Identity, 185-206.

14 Kaldellis, Byzantine Republic, 2-31. Communities, 6-7 and 15; Hobsbawm, Nations and Nationalisms, 176. On analogies between empire and nationstate, see Kumar, Nation-States as Empires. 
In an excerpt from the early-fifth century history of Eunapius, for instance, one reads that »it was clear to all that if the Roman imperial power rejected luxury and embraced war, it would conquer and enslave all the world. But God has set a deadly trait in human nature, like the poisonous gall in a lobster or thorns on a rose. For in high authority he has implanted love of pleasure, with the result that, while they have all means with which to unite mankind and turn it into a single polity (politeia), our Emperors in their concern for the transient turn to pleasure without taking into account and showing interest in the immortality of glory «. ${ }^{17}$ This late-Roman vision of an elusive pax romana demonstrates that the boundaries of the Roman polity were not conceived in culturally exclusive terms. They were determined by the limits of imperial authority, which could be expanded through means of war in order to include as many peoples as possible, thus making them members of a single Roman political community. ${ }^{18}$ The term Rhomaiōn politeia - like the terms Rhomaiōn archê, Rhomaiōn basileia or Romania - was bound to the vision of a territorial empire sine fine whose Roman identity was determined by an imperial city-state, Rome and New Rome, respectively.

In the early-tenth century, Leo VI (886-912) reasserted the image of the Rhomaion politeia as a geopolitical order demarcated by the fluctuating boundaries of Roman imperial authority. He remarked that the Saracens bordered on his politeia and harmed his subjects (to hypêkoon), thus causing no less trouble to him than the former neighbouring people of the Persians did to the emperors of old. ${ }^{19} \mathrm{~A}$ few decades later, Constantine VII designated Constantinople as the reigning city of the whole world and distinguished between the changes that had taken place within the limits of the current Roman realm (politeia) and those that had occurred within the limits of the Roman Empire (Rhomaiōn archê) in different times. ${ }^{20}$ It has been suggested that for Constantine VII politeia did not refer to the whole realm currently under imperial rule but mainly to the city-state of Constantinople. ${ }^{21}$

In my view, the two interpretations need not be mutually exclusive. For the Byzantines, the image of the Rhomaion politeia was archetypally bound to the city of New Rome and its emperor. It was through the expansion of the emperor's enforceable legal, fiscal, and military authority over regions and their populations that the territoriality of the empire as an extended polity of Roman law and order came into being. For instance, the author of the deeds of Emperor Basil I (867-886) wrote that due to lack of time he decided to treat the reign of a single emperor, even though his wish was to narrate the more noteworthy deeds accomplished throughout the entire duration of the Roman power in the city of Byzantium: the deeds of emperors, of officials serving under them, of generals and their lieutenants, and so on. ${ }^{22}$ In another part of the text, he reported on an impending Muslim attack against the seas and the lands that paid tribute (hypoforoi) to the Rhomaioi ${ }^{23}$ In the mid-tenth century,

18 The same stance was still held in mid-twelfth century Constantinople; Anna Komnene, Alexias, VI 11, 3, ed. Reinsch and Kambylis, 193.

19 Leonis VI Tactica, XVIII 135, ed. Dennis, 488, 690-692.

20 De thematibus, 1, 1-4 and 1, 39-40, ed. Pertusi, 84; De administrando imperio, Proem 22-24, ed. Moravcsik, 46; For this interpretation, Sode, Untersuchungen, 160-161.

21 Magdalino, Historical Geography, 39.

22 Vita Basilii, 1, 3-14, ed. Sevčenko, 8-10.

23 Vita Basilii, 68, 6-7, ed. Sevčenko, 235. 
the history of the Rhomaioi (their Zeitgeschichte) was that of the people of a reigning citystate whose boundaries could extend in geopolitical terms to include all subject populations and regions that paid tribute to the imperial power of Constantinople and were governed by its laws through its agents, the members of the imperial élite of service.

That the populations of the empire had a clear image of belonging to an imperial political order demarcated by the fluctuating limits of the Roman emperor's authority is made evident in provincial texts as well as in hagiography. The seventh-century Doctrina Jacobi presented a Jewish merchant in Carthago stating that up to those times the territory of the Romans had extended from Spain in the West to Persia in the East and from Africa in the South to Britain in the North, and that the Roman boundaries were still visible due to the marble and bronze monuments of the emperors. All these peoples had been subordinated to the Romans by the will of God, but now one could see the Roman realm (Romania) been humbled. ${ }^{24}$

A similar geopolitical image of the Roman community can be found in the most popular version of the ninth-century collective martyrion of the 42 Martyrs of Amorion. According to the author, the Romania - the realm of Roman imperial authority - had taken its current shape after the territorial contraction of Roman imperial rule in the seventh century due to the rulers' heresy that had brought the Muslim conquest. ${ }^{25}$ By the end of the seventh century the lost eastern provinces and their populations - that had been for centuries under Roman rule - were no longer viewed as Roman, even though Christian identity played an important role in maintaining certain bonds with the Christian Empire, as testified by the various ways eastern Christians of different doctrines continued to look upon the Roman power of Constantinople. ${ }^{26}$

Within this framework, developments of the late-sixth century brought an end to the division of Roman élite culture between Latin and Greek. In the seventh-century Vita of St Anastasios the Persian, the Greek language was referred to as the Roman way of speaking (rhomaisti) $^{27}$. This seems to be a unique use of the adverb rhomaisti, since Byzantine authors consistently employed it to refer to the Latin language, as opposed to graikisti or hellênisti for the Greek language. ${ }^{28}$ Nonetheless, in the aftermath of the so-called dark centuries a main presupposition for becoming Roman was a knowledge of Greek - which was designated as the voice or language of the Rhomaioi. ${ }^{29}$ Due to these changes, Byzantine Romanness now fulfilled many of the basic criteria of a dominant ethnicity according to Anthony D. Smith's definition. ${ }^{30}$ It was based on a single script and language, a single religion determined by the Chalcedonian doctrine, Roman law and canon law as well as by the political customs of the Roman imperial power.

24 Doctrina Jacobi III, 10, ed. Déroche, 169.

25 Evodius, Vita martyrum XLII Amoriensum, ed. Nikitin/Vasilievskij, 63 and 75. Cf. De thematibus, 1, 8-21, ed. Pertusi, 59-60. For the opposite image of expansion of the Roman political boundaries in the tenth century, Theophanes Continuatus (liber VI), ed. Bekker, 426-427.

26 On the development and change of the content of Byzantine Romanness during the period of the Muslim expansion, see Haldon, Empire That Would Not Die, 79-119.

27 Anastasios the Persian, Life and Miracles, 43, ed. Flusin, 89.

28 Koder, Sprache als Identitätsmerkmal, 10-16.

29 Theophanes, Chronographia, ed. De Boor, 455, 24-25; Vita Basilii, 68, 10, ed. Sevčenko, 234; Theophanes Continuatus (liber VI), ed. Bekker, 407, 15-16.

30 Smith, Cultural Foundations of Nations, 30-31. 
However, a closer look at the identity discourse of Byzantine authors in the wake of the reform period of the »dark centuries«shows that the Rhomaioi did not conceptualize their identity in terms of common ethnic descent. Prominent examples that showcase this are Roman emperors such as Leo V (813-820) and Basil I (867-886) whose Armenian origins are highlighted in the sources. The former had migrated from Armenia to the Empire at a young age and through a career in the army had managed to usurp the throne. ${ }^{31}$ Basil I's case is even more interesting because he was a native of the empire. Nevertheless, his grandson and biographer Constantine VII not only spoke of Basil as an Armenian by origin, but also presented his Armenian identity as a factor in his social relations at the court. ${ }^{32}$ Constantine's only concern was to hush up Basil's humble origin from Armenian peasant settlers in the region of Thrace by inventing a fictitious descent from families of royal pedigree, such as the Armenian Arsacids on his father's side and the families of Constantine I and Alexander the Great on his mother's side. ${ }^{33}$

Such practices of ethno-cultural classification of Roman subjects by Byzantine authors, which are omnipresent in the sources, indicate that despite the extensive political and cultural changes of the previous period Byzantine Romanness maintained the character of a dominant political discourse. This political discourse was underpinned by a reshaped dominant (élite) culture and promoted the vision of an imperial body politic in which various subaltern visions of community (e.g. ethnic or religious) were accommodated. This development needs to be assessed in relation to the policies of the Roman imperial state after the late-seventh century, which had consistently reinforced and expanded the political body of Roman subjects through the injection of a large number of ethno-culturally diverse populations, such as Slavs, Armenians, Syrians, and Paulicians, to name some of the most prominent groups that the emperors of Constantinople either subjugated along with their areas of settlement (for instance, Slavs in Greece) or transplanted into depopulated regions of the Empire (Armenians and Syrians in Thrace, Slavs in Asia Minor). ${ }^{34}$ Byzantine law demonstrates that what differentiated the legal-political status of new and old members of the imperial politeia was not ethnic background or indigeneity, but religious doctrine. Chalcedonian Christianity was the main precondition for a Roman subject to enjoy the full legal-political rights of Romanness, thus promoting its ethno-religious content. ${ }^{35}$ Underneath the normative surface of imperial law, however, the evidence of other sources reveals a more nuanced reality about the relationship of the imperial state with its non-Chalcedonian subjects.

The case of the Christian sect of the Paulicians is indicative of this social reality. In his effort to depict a dark picture of Emperor Nikephoros I (802-811), Theophanes the Confessor accused him - among other things - of having a lenient attitude towards the sects of the Paulicians and the Athinganoi, reporting that "these were given leave during his reign to

Theophanes Continuatus (libri I-IV), 1-12, ed. Featherstone and Codoñer, 12-39.

Vita Basilii, 12, 24-27, ed. Sevčenko, 48, where the friendly relationship between Basil and a patrician named Constantine at the court is related to their common Armenian origin.

Vita Basilii, 2-3, ed. Sevčenko, 10-19. Cf. Markopoulos, Roman Antiquarianism, 287.

Ditten, Ethnische Verschiebungen, 123-305. On ethnic diversity as a factor of social relations within the empire, see Curta, Burial in Early Medieval Greece, passim.

On the restricted rights of heretics that excluded them from public office, see Basilicorum Libri LX, 1, 1, ed. Scheltema, 1-14. 
conduct their own way of life (politeuesthai) without fear so that many light-headed people became corrupted by their illicit doctrines «. ${ }^{36}$ The martyrion of Kallistos, one of the 42 Martyrs of Amorion, written in the second half of the ninth century, indicates that this 'lenient attitude - which had little to do with tolerance but rather more with the weakness of a pre-modern state to pervade and control society in the way the modern infrastructural state is able to do - was not confined to a single emperor: Paulicians held minor positions in the provincial administration in Asia Minor during the reign of Emperor Theophilos (829-842). ${ }^{37}$

The emergence of an autonomous Paulician principality with Muslim support in the East in the mid-ninth century is regarded as a reaction to imperial persecution, but its subjugation by Emperor Basil I in 878 led neither to the community's elimination nor to forced conversion. Evidently instead, a part of the Paulician population was integrated to the imperial body politic and, almost a century later, John I Tzimiskes (969-976) resettled them to Thrace, where they functioned as an ordinary and productive population that paid taxes and, despite their heretic identity, served in the emperors' armies - at least until their persecution by Alexios Komnenos (1081-1118)..$^{38}$

This evidence indicates that religious identity may have differentiated the rights and the degree of loyalty of Roman subjects to the imperial power of Constantinople, as well as the potential of their members for social advancement, since - at least nominally - conversion to the Chalcedonian doctrine was a main precondition to enter the Roman elite and make a career at court. ${ }^{39}$ Nonetheless, the largest part of non-Chalcedonian subjects shared with their Chalcedonian counterparts similar obligations towards the state and the same basic perception of being members of an imperial order, demarcated by the limits of the emperor's enforceable authority.

\section{Imperial Romanness vs. dominant Roman ethnicity}

If Romanness was the only meaningful identity to perform for any person that advanced socially and exceeded the limits of the regional homeland within the Empire, it is worth taking a closer look at the content of this collective identity at the level of common provincials. The early-tenth century Tactica of Emperor Leo VI (886-912) is a particularly valuable source of evidence in this regard, for it provides information on the real mechanisms of collective identity-building on the battlefield, namely the transmission - in various languages of clear-cut messages to each small unit (bandon) before battle by the so-called kantatores or mandatores.$^{40}$ Contrary to the rhetorically charged military harangues in Constantinopolitan histories, which were never delivered to the common soldiers in the reported manner and whose content was usually an invention of the educated author adapted to the literary

36 Theophanes, Chronographia, ed. de Boor, 488. In this context, the verb politeuesthai does not refer to citizenship rights (as translated in Mango and Scott, The Chronicle of Theophanes Confessor, 671), but rather to the heretics' ability to maintain and publicly profess their confession.

37 Michael Synkellus, Encomium, ed. Nikitin and Vasilievskij, 29.

38 Skylitzes, Synopsis, ed. Thurn, 286, 62-6. Cf. Lilie, Minderheiten in Byzanz, 312-215.

39 On converted Muslims (with some exceptions of non-converts) in the imperial administration, see Cheynet, L'apport arabe à l'aristocratie byzantine, 137-146. On the important role of Armenians in the empire, both Monophysite and converts, see Garsoian, Armenian Integration, 53-124.

40 Leonis Tactica, IV 7, XII 56-57, ed. Dennis, 50, 248. 
expectations of an élite audience, ${ }^{41}$ the exhortations of the Tactica provide an insight into those common ideas that in the Constantinopolitan ruling élite's view appealed to common provincials, from whence the main bulk of the recruits came. Therefore, they are the closest we can get to a collective identification of Roman subjects. According to the author, the heralds should:

First, call to mind the reward for their faith in God and the benefactions of the emperor, and some of their previous victories; and that the struggle is on behalf of God and their love to him and on behalf of the entire people (ethnos). Furthermore, it is on behalf of their brothers of the same faith and, if it applies, for their wives and children and their fatherland (patris). Eternal indeed remains the memory of those who have valiantly striven against the foe on behalf of the freedom of their brothers, and the whole struggle is against the enemies of God. We have God as our friend who has power over the outcome of war, whereas they have him as opponent due to their faithlessness towards him. ${ }^{42}$

These lines have been interpreted as a patriotic manifesto containing the principal values of Byzantine (sic) nationalism that united soldiers of various ethnic origins in what had become a national army after the seventh century ${ }^{43}$ This interpretation relies on a decontextualized and anachronistic interpretation of the terms ethnos and patris. To begin with, in Byzantine usage the term ethnos could denote an army, the people of a city or a province, a community of common culture (an ethnic group) or even the members of a world-religion. The author of the Tactica - like his contemporary historiographers - never uses the term Rhomaion ethnos to designate the Roman community. He only refers once to a struggle on behalf of the entire ethnos Christianōn in another part of the treatise. ${ }^{44}$ This is usually interpreted as an allusion to the Roman people as a Christian people (in the sense of a 'Chosen Peopler) because Byzantine authors often employed the collective designation Christianoi as a substitute for Rhomaioi in their writings. However, in Byzantine perception - just as in social reality the boundaries of the ethnos Christianon exceeded those of the Roman community. ${ }^{45}$

In light of this, the term ethnos in the passage cited above - if not an allusion to the army ${ }^{46}$ - had very little to do with a vision of community based on a shared ethnic or, even less so, national Roman identity as the discourse concerning brothers of the same faith instead of Roman brothers - indicates. In the author's view, what could promote solidarity among indigenous and foreign recruits of various ethnic and doctrinal backgrounds, and

41 Lilie, Reality and Invention, 208; On Byzantine written sources as mainly the products of an educated élite for an élite audience, see Lilie, Byzantinische Gesellschaft, passim; Croke, Uncovering Byzantium's Historiographical Audience, 25-53.

42 Leonis VI Tactica, XII 57, ed. Dennis, 248. The designation »enemies of God«, against which the Byzantines fought with God's help, was equally applied to (orthodox) Christian enemies that attacked the Christian Empire because they violated the Christian principle of brotherhood and peace, see Stouraitis, Krieg und Frieden, 304327, esp. 308-310.

43 Ahrweiler, Ideologie, 29-36; Browning, Greeks and Others, 14.

44 Leonis VI Tactica XVIII 19, ed. Dennis, 444.

45 E.g. Nikolaos I Mystikos, Epist. 32, 472-473, ed. Jenkins and Westerink, 242.

46 For the frequent use of the term ethnos as an equivalent of army in the text, see Leonis VI Tactica XII 27 and 106, XIII 13, XIV 99, XV 62, XVIII 57 and 72, epilogue 44, ed. Dennis, 232, 272, 284, 346, 378, 456, 462, 630. 
make them identify with these populations for whose freedom they were called to fight, was a shared religious culture. Moreover, the image evoked of a community of Christian brothers was ambiguous enough to refer to Christians both within and outside the boundaries of Roman rule - in particular those Christians under Muslim rule in the East, where the Constantinopolitan power sought to expand its authority, as testified by contemporary texts. ${ }^{47}$ In this context, the imperial power heeded the fact that neither all its soldiers nor all Christians in the empire's geopolitical sphere adhered to the Chalcedonian doctrine. ${ }^{48}$ Chalcedonian orthodoxy may have been the state's official ideology, but a closer look at the propagated religious ideals indicates that these were uttered in a manner free of any theological concern for orthodoxy, so that they could include and apply to Chalcedonian and non-Chalcedonian Christians alike.

The propagated notion of patris in the exhortations to the common soldiers further confirms that the operative ideology employed to underpin the loyalty of common provincials to the Roman imperial rule of Constantinople had little to do with a broader vision of Roman patriotism (i.e. proto-nationalism), either of religious (Chalcedonian) or of political (republican) content. The bulk of the provincial armies of the early-tenth century consisted of indigenous soldiers who were recruited from the area of the thema (province) in which their unit (also called thema) was permanently stationed..$^{49}$ When the author instructed that the soldiers should be exhorted to fight on behalf of women, children and homeland (when this applied), it is evident that such a message was relevant only when the thematic soldiers were called to defend the region where their families lived in their own hometowns. The ruling élite was well aware that for common provincials a politicized image of the patris could only refer to their regional homeland and not to a territorially abstract and indefinable entity like the Empire, the Romania, an alleged patria communis of all Christian-Romans.

Other sources verify the distinction between an élite vision of imperial patriotism bound to the city-state of Constantinople as the archetypal patria communis of the Rhomaioi, and the predominant perception of patris among common provincials as the local/regional homeland. According to Theophanes Continuatus, when Emperor Romanos Lekapenos (919-944) exhorted the leaders of the imperial regiments to march out against the Bulgars that were attacking the Constantinopolitan suburbs in order to protect the fatherland (patris), they readily agreed to die on behalf of his imperial power and the Christians (i.e. the Rhomaioi). ${ }^{50}$ This image of the imperial city as a common homeland of the Christian-Romans appealed both to the high-ranking officers of the imperial regiments as well as the élite audience of the text. ${ }^{51}$

47 Arethas, Scripta Minora II 33, 14-34, 6, ed. Westerink, 62.

48 On Monophysite Armenians and Paulicians as recruits in the imperial armies, see Lilie, Minderheiten in Byzanz, 305-308 and 314 .

49 Brubaker and Haldon, Byzantium in the Iconoclast Era, 744-755.

50 Theophanes Continuatus (liber VI), ed. Becker, 402-403. The designation of the Rhomaioi as Christianoi in a conflict against the (also Chalcedonian) Christian Bulgars relates to the role of religion in justifying Byzantine defensive warfare against enemies of the same faith; cf. n. 42 above.

51 For similar images of imperial patriotism, cf. Kinnamos, Epitome, ed. Meinecke, 173; Choniates, Historia, ed. Van Dieten, 529, 20-26. 
In a contrary instance, in an anonymous military treatise on campaign organization, written in the late-tenth century, the author refers to the soldiers dwelling on the borders of the Roman realm and observes that they should be protected from the excesses of tax-collectors and be respected and honoured as defenders of the Christians in order to "to eagerly endure dangers for our holy emperor and their own homeland «. ${ }^{22}$ Here, the author's discourse demonstrates once again that, while the emperor as the common leader of all Romans (our basileus) was the main point of reference that united politically the borderlands with the imperial centre, the political patris which provincial soldiers were called to defend referred to their own regional homeland (tês heautön patridos) and not to some common broader Roman land. ${ }^{53}$ Similarly, Niketas Choniates reported, in regard to an impending clash with the Turks in the spring of 1199, that the soldiers were assembled to fight the enemy and either defeat him or die gloriously on behalf of their homelands (patrides). ${ }^{54}$

It is in this ideological context that the author of the Tactica instructed the generals of the provincial armies to inspire those soldiers that were found lacking of patriotic sentiments with love of the homeland and obedience to their officers either through affection or through fear! ${ }^{55}$ Moreover, the general should also promise the soldiers rewards and benefactions from the emperor and recompense (misthon) for their loyalty to the politeia in the days preceding battle. ${ }^{56}$ The imperial power was well aware that the indigenous recruits were not volunteers, but an army of mercenaries. ${ }^{57}$ Their loyalty to the imperial polity of Constantinople was not determined by ideals of nationhood, but by regular reward from their employer, the Roman imperial power. Along these lines, the late-eleventh century treatise of the provincial magnate Kekaumenos advised the emperor to take great care of his soldiers and don't cut their pay, because they were selling him their own blood. ${ }^{8}$

The evidence presented so far sets the background against which the salience of a fullblown discourse of Roman ethnicity in high medieval Byzantium needs to be addressed. The late-tenth century history of Leo the Deacon testifies to an image of the Rhomaioi as a distinct ethno-cultural category within the boundaries of the Roman imperial polity. The author reports that after the reconquest of Crete from the Muslims in 961 General Nikephoros Phokas settled families of Armenians, Rhomaioi, and other rabble there in the process of the island's re-Romanization. ${ }^{59}$ In this case, the labels Roman and Armenian were not employed to distinguish between members and non-members of the imperial politeia, respectively. Evidently both groups were considered and treated as full members (i.e. subjects) of the Roman imperial polity with equal rights and obligations, since they were transferred and given lands on Crete.

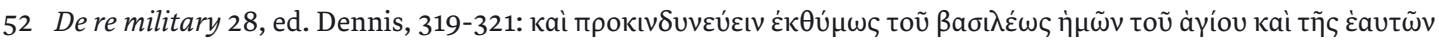

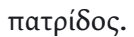

53 Cf. the case of a Muslim attack against Attaleia in the early-ninth century, where local patriotism and common Christian identity inspired the local garrison, Life of St Antony the Younger, ed. Papadopoulos-Kerameus, 186216.

54 Choniates, Historia, ed. Van Dieten, 496, 17-24. Elsewhere, Choniates explicitly relates the notion of a fight for women and children with the defence of the hometown, ibid. 30, 7-15.

55 Leonis VI Tactica XVIII 16-17, ed. Dennis, 442-444.

56 Leonis VI Tactica XIII 4, ed. Dennis, 278.

57 Stouraitis, Just War, 256-258.

58 Kekaumenos, Consilia et Narrationes, VII, ed. Rouché, 94, 24-95, 2.

59 Leo Diakonos, Historia, ed. Hase, 28; Talbot and Sullivan, The History of Leo the Deacon, 80. 
Therefore, in this context the content of the term Rhomaios was not political but rather ethno-cultural, demarcated by certain selected cultural markers - primarily the Chalcedonian doctrine and the Greek language. This is further supported if one juxtaposes Leo the Deacon's discourse with the discourse of De administrando imperio in an analogous case a few decades earlier. The latter distinguished between the Slavs and the Graikoi as two ethnocultural categories of imperial subjects in the region of the Peloponnese.$^{60}$ In this case the label Graikoi demarcated the Greek-speaking Chalcedonian subjects of the emperor, that is, the same category of imperial subjects that Leo the Deacon chose to designate as Rhomaioi.

By the late-eleventh century notions of Romanness as an identity of descent had become salient in Constantinopolitan historiography. John Skylitzes reported that the Bulgar ruler Boris summoned a painter, "a monk named Methodios, who was Rhomaios by birth «to decorate his new house. ${ }^{61}$ What makes this report interesting is that Skylitzes changed the discourse of his source, namely the mid-tenth century text of Theophanes Continuatus, which reported on "a certain monk from amongst us Rhomaioi «. ${ }^{62}$ Furthermore, twelfth-century historiographers broke with the normative practice of previous centuries that confined Romanness to populations within the boundaries of the imperial polity - a common exception being prisoners of war - and occasionally labelled Christian populations in the Seljuk territories of Asia Minor as Rhomaioi. ${ }^{63}$

Taking these developments into account, it is worth noticing that Roman ethno-cultural identity functioned neither as a precondition nor as a marker of loyalty to the Roman imperial polity ${ }^{64}$ For instance, John Kinnamos labelled the indigenous Christian population at Lake Pousgouse in Seljuk Asia Minor as Rhomaioi despite the fact that these people were outside the borders of the Rhomaion politeia and showed no sign of political loyalty to it by actively resisting John II's (1118-1143) effort to reintegrate them. ${ }^{65}$ Here, the author opted for Romanness as a fixed ethno-cultural identity of shared cultural markers free of any political content. Contrarily, his contemporary Niketas Choniates labelled them as Christians and characterised them as enemies of the Rhomaioi, even though he, too, was inclined to acknowledge bonds of common kinship and religion with them. ${ }^{66}$ Thus, he justified John II's actions to destroy them by stating that they had no right to their land as it was an ancient possession of the Rhomaioi ${ }^{67}$ Here, the Rhomaioi were not envisaged as a people demarcated by common kinship and shared cultural makers within an abstract (ethnic) homeland, but as the political community of the city-state of New Rome, whose territorial boundaries extended as far as the boundaries of imperial authority.

60 De administrando imperio, 49, 4-9, ed. Moravcsik, 228. Cf. Stouraitis, Roman Identity, 208-209. For a similar discourse of ethno-cultural contradistinction between Graikoi and Bulgars, see Vita Clementis, ed. Milev, 68, 1-4.

61 Skylitzes, Synopsis, ed. Thurn, 91; On similar ethnic discourses cf. Kinnamos, Epitome, ed. Meinecke, 56 and 251; Choniates, Historia, ed. van Dieten, 37 and 190.

62 Theophanes Continuatus (libri I-IV) IV 15, ed. Featherstone and Codoñer, 232-234.

63 Anna Komnene, Alexias, XI 8, 2, ed. Reinsch and Kamvylis, 346; Kinnamos, Epitome, ed. Meinecke, 22. Cf. Page, Being Byzantine, 79-84.

64 Stouraitis, Roman Identity, 201-202.

65 Kinnamos, Epitome, ed. Meinecke, 22.

66 Choniates, Historia, ed. van Dieten, 37; cf. Page, Being Byzantine, 83.

67 Choniates, Historia, ed. van Dieten, 38. 
Choniates' choice to propagate Romanness as an identity of loyalty to the imperial polity in this case corresponds to the socio-political reality of high medieval Byzantium, in which the role of ethnicity remained marginal in circumscribing political identifications and stateorganisation. Christian identity and loyalty to the emperor continued to be the main criteria for becoming a full member of the Roman imperial politeia. For instance, a eunuch of Saracen origin could perform a Roman identity as a leading officer of the imperial army under Emperor Constantine IX (1042-1055) due to his loyal service to the emperor since before the latter's rise to the throne. ${ }^{68}$ Similarly, groups of Pechenegs could be integrated into the Roman imperial polity through baptism and become taxpaying imperial subjects with both basic rights to land and an obligation for military service as all other common subjects of the emperor did. Even though such populations maintained their generic image as barbarians in cultural terms in the discourse of the educated Roman élite, ${ }^{69}$ this hardly hindered some of their members to advance socially and enter the imperial élite of service by acquiring higher ranks and titles. ${ }^{70}$

There are numerous examples of newcomers of various ethnic origins - mainly Bulgars and Armenians after the subjugation of their lands in the eleventh century, as well as Latins in the twelfth century - who received Roman titles and offices, thus performing Romanness as an identity of loyalty to the emperor and the Roman political order. ${ }^{71}$ In this regard, when Choniates in retrospect criticized the practice of Emperor Manuel I Komnenos (11431180) of preferring barbarians over Rhomaioi for offices in the provincial administration and the army ${ }^{72}$ his stance implies a proto-national approach to the organization of the state, an approach that had indeed very little to do with the functioning of the Roman order as an imperial-political community of subjects whose rights and privileges were not determined by ethnic origin and indigeneity, but by religious affiliation and degree of loyalty to the imperial power of Constantinople.

Within this framework, the role of the reigning city of New Rome as the principal source of Roman peoplehood and political legitimacy was central in the construction of the historical past of the Rhomaioi by the educated élite. In the introduction of his world-chronicle, written in the first half of the twelfth century, John Zonaras mentions that within the framework of world-history his main goal is to narrate the history of the Romans, which stretched from the foundation of the city of Rome to the emperors of his own days. According to him, the major events of this history concerned the changes of the political system of the city of Rome (from kingship to tyranny and from aristocracy to democracy, and then to autocracy); the Christianization of the empire by Constantine I and the transfer of the imperial power by him from Rome to New Rome - Constantinople; and, finally, the deeds of all of the emperors that had succeeded Constantine I up to the author's time. ${ }^{73}$

68 Skylitzes, Synospis, ed. Thurn, 438.

69 In the discourse of the educated élite common Rhomaioi were occasionally presented as barbarian in culture as well; Stouraitis, Roman Identity, 198-200.

70 Attaleiates, Historia, ed. Pérez Martín, 66. Cf. Stephenson, Balkan Frontier, 96-98.

71 E.g. Skylitzes, Synopsis, ed. Thurn, 344, 346, 354-355, 357-358, 359, 436-437; Choniates, Historia, ed. van Dieten, 171, 202.

72 Choniates, Historia, ed. van Dieten, 205, 4-26 and 209, 1-14.

73 Zonaras, Epitome, ed. Dindorf, I 8-11. 
An analogous scheme of historical continuity was already introduced in the late-eleventh century Historia Syntomos of Michael Psellos, which began with the foundation of Rome and briefly portrayed Roman kings, consuls and emperors up to the time of Basil II (976-1025). ${ }^{74}$ In this view of the historical past, cultural and territorial discontinuities between the ancient and the medieval Romans were completely irrelevant for the authors and their audience. What determined their notion of historical Roman peoplehood and legitimized their perception of Roman political culture as their ancestral culture was a belief in the unbroken continuity of a Roman city-state due to the translatio imperii that had sealed the relocation of Roman imperial culture along with the archetypal Roman city-patria from the banks of Tiber in the West to the shores of the Bosporus in the East. This image of the past legitimized the educated élite to label subject populations as Ausones in a classicizing manner ${ }^{75}$ and entitled Emperor Constantine VII to speak of Latin as the ancestral Roman language,$^{76}$ although he was a Greek-speaker who presented his own grandfather as Armenian by origin.

\section{Ethnicity without a group}

Considering that the configuration of a dominant Roman ethnicity changed very little in the form and function of the high-medieval eastern Roman community as an imperial political order, the swift loss of Anatolia to the Seljuks in the 1170s and the events of the following period up to the disintegration of the Empire in 1204 indicate that eastern Roman ethnic discourse neither promoted a stronger Wir-Gefühl nor enhanced provincial loyalty to the Rhomaion politeia of Constantinople. Loyalty or disloyalty to the centre remained principally a matter of power relations, personal ties of provincial magnates to the imperial court and the bilateral relationship between the local/regional community and the imperial capital. In this context, provincial élites and populations surrendered and cooperated with the enemies of the Rhomaioi when this seemed to be in their local interest. ${ }^{77}$ The loyalty of the provinces to the centre waned incrementally, with provincial populations actively or passively supporting lords that pursed political separatism. ${ }^{78}$ Last but not least, Rhomaioi under Seljuk rule were often disinclined to return to Roman authority when the possibility occurred. ${ }^{79}$

The detailed account of Niketas Choniates on the events that followed the sack of Constantinople demonstrates that loyalties and identifications at the local/regional level came first, supplanting ethnic bonds or any identification with the common good and interest of a united Roman community. ${ }^{80}$ The author explicitly criticized the Rhomaioi of western Anatolia because after having escaped the Latin danger they did not seek to support their fellow countrymen in Thrace who were under Latin attack. Instead, he stated, they chose to remain divided into factions, fight against one another and incite cities to revolt, thus

\footnotetext{
74 Markopoulos, Roman Antiquarianism, 294-295.

75 E.g. Attaleiates, Historia, ed. Pérez Martín, 31.

76 De thematibus, I 24-25, ed. Pertusi, 60.

77 See e.g. Anna Komnene, Alexias, V 4, 1 and X 3, 1, ed. Reinch and Kamvylis, 149 and 287; Kinnamos, Epitome, ed. Meinecke, 22; Choniates, Historia, ed. van Dieten, 37-38, 72-73, 75-76.

78 For the phenomenon of provincialism before 1204, see Hoffmann, Rudimente, 5-76; Lilie, Macht und Ohnmacht, 9-120; Cheynet, Pouvoir, 379-404, 446-74.

79 Kinnamos, Epitome, ed. Meinecke, 22, 296; Choniates, Historia, ed. van Dieten, 37-38, 495-496.

80 Choniates, Historia, ed. van Dieten, 599-610.
} 
ignoring the bonds of kinship. ${ }^{81}$ The same was true for the Rhomaioi of Greece, where many local magnates either submitted willingly to the Latins or were more concerned with creating their own autonomous principalities. ${ }^{82}$ This criticism, besides confirming the proto-national traits in Choniates' thought in the wake of 1204, testifies to the role of the Fourth Crusade in revealing the lack of an operative ideology that could promote ethnic or, for that matter, national solidarity among the Rhomaioi in the face of a deteriorating imperial political superstructure. By the end of the first decade of the thirteenth century, various Byzantine principalities (Nicaea, Epirus und Trebizond being the three major ones) had emerged next to the Latin domains in the former Roman realm with conflicting political interests.

These developments are indicative of the ideological background of Romanness as a dominant political discourse of collective identification in the previous centuries. It was neither shared cultural markers nor a shared belief in an alleged republic of the sovereign Roman people that had determined the unity of the eastern Roman political community, but the charisma of the imperial office, underpinned by the predominant belief in the divinely-ordained monocracy of the Christian-Roman emperor of New Rome. The regression of this operative ideology among the members of the élite culminated with the loss of the imperial city. This is testified in an elucidating manner by a letter from the bishop of Naupaktos John Apokaukos (representing the interests of the ruler of Epirus) to the Patriarch of Nicaea Manuel I in 1222.

Apokaukos claimed that, even though the notion that there should be only one emperor over worldly affairs and a single shepherd of ecclesiastical affairs respectively was correct, the sins of the Romans had caused the empire's division into many parts. So, despite the common religion that united them all, they remained divided under various political and religious authorities due to God's will. ${ }^{83}$ This statement pinpoints how the belief in divine ordainment was now employed to legitimize a new status quo in which the Rhomaioi- as a collectivity of a common culture - were allowed by God's will to create various polities, each with its own ruler to whom political loyalty was due. ${ }^{84}$ For the archbishop of Ochrid, Demetrios Chomatenos, the ruler of Epirus was no less legitimate than the ruler of Nicaea, since the practice of imperial monocracy had been relinquished along with the loss of Constantinople. ${ }^{85}$

In this context, when Nikephoros Blemmydes argued from a Nicaean point of view that all those of the same origin (omogeneis) should be under a single authority, or when Michael Choniates exalted the ruler of Nicaea as the future liberator of the Romania, their statements had little to do with a shared proto-national vision among the Rhomaioi.$^{86}$ This is confirmed by the fact that after the recapture of Constantinople by Michael VII of Nicaea in 1261 the other Roman polities were not willing to be reunited into a single imperial politeia. The restored Constantinopolitan state sought to reinstate imperial Romanness by claiming that the ruler of Epirus had no longer the right to hold his lands since the emperor was no more

81 Choniates, Historia, ed. van Dieten, 625 and 639.

82 Choniates, Historia, ed. van Dieten, 637.

83 Vasilievsky, Epirotica saeculi XIII, 276, 27-277, 14.

84 A similar stance adopted the bishop of Corfu George Bardanes in his letter to the Patriarch of Nicaea Germanos II; George Bardanes, Epistula ad Germanum II, 18, ed. Loenertz 117, 413-422.

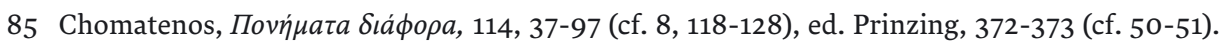

86 Nikephoros Blemmydes, Curriculum vitae, 1, 23, 4-10, ed. Munitiz, 14; Michael Choniates, Epist. 138, 20-26, ed. Kolobou, 226. 
outside the patris (i.e. Constantinople). Michael II Angelos' response that his family had taken the territory from the Latins and not from the Romans demonstrates that this identity remained a dead letter. ${ }^{87}$

Notions of common ethno-cultural identity remained irrelevant in the long-drawn process of reunification of the Rhomaioi under Constantinopolitan overlordship after 1261. During the negotiations for the surrender of the city of Arta in the Despotate of Epirus in 1339/40, the representative of Emperor Andronikos III John Kantakouzenos argued that it was unjust that the Arteans had accepted the barbarian Tarantines ${ }^{88}$ as their rulers instead of the Roman power of Constantinople, which had ruled their ancestors since the time of Caesar. For this reason, he justified the emperor's campaign against the city as a divinely-ordained restoration of his rightful ancestral authority over the territory, since he was by means of continuous succession the descendent of the ancient Roman emperors. ${ }^{89}$ In their response the Arteans argued that, although their loyalty to the local Angeloi dynasty had been just, they would surrender to the emperor due to their hopeless military position, which threatened to destroy them and their fatherland (patris) instead of preserving their freedom. ${ }^{90}$

From the Constantinopolitan point of view, political unity was not claimed in terms of common kinship and cultural peoplehood (or, for that matter, identification with the vision of a united Roman republic), but as recognition of the ancestral right of the holder of the Roman throne of Constantinople to exercise centralized authority over those territories and populations that had been ruled by his predecessors since the time of Augustus. ${ }^{91}$ The response of the Arteans provides further evidence that for provincial populations local/regional identities and loyalties prevailed over any identification with a Rhomaiōn genos or a Rhomaiōn politeia as a cultural or political entity. ${ }^{92}$ Their patriotism referred to the notion of the freedom of their city-patria, whereas they regarded subordination to the Roman imperial power of Constantinople as subservience (douleia).

The vision of the Rhomaioi as a people of common kinship and culture remained at odds with the vision of a Roman political community whose boundaries were demarcated by the limits of imperial authority. Late-Byzantine Constantinopolitan historiographers remained faithful to the latter concept and propagated Romanness as an identity of membership and loyalty to the polity of the imperial power of Constantinople (or Nicaea for the period of exile). ${ }^{93}$ Within this framework, they employed the term emphylios polemos (internal armed conflict) in the traditional strictly political manner in order to designate only those conflicts over the throne within the late-Byzantine imperial state-frame and not the wars between the Rhomaioi of Constantinople (or previously Nicaea) and those of the other polities. ${ }^{94}$

87 Pachymeres, Historiae, ed. Failler, I 272, 22-275, 15.

88 This is a reference to the alliance of the Angeloi dynasty of Epirus with Philip of Taranto.

89 Cantacuzenus, Historiae, ed. Schopen, I 520, 1-521, 19.

90 Cantacuzenus, Historiae, ed. Schopen, I 523, 1-524, 6. On various notions of patris in late Byzantium, see Kiousopoulou, Emperor or Manager, 141-165

91 Fatouros and Krischer, Geschichte II, 245, n. 332. This legitimized the emperor to use Turkish mercenaries to impose his direct rule over dissident Rhomaioi, cf. Kyriakidis, Warfare, 32.

92 Cf. the case of the local archontes of Ioannina who pledged loyalty to their despot Carlo Tocco (1411-1429), promising that they would not exchange him for the emperor, see Chronicon Toccorum, IV 5, 1236, ed. Schirò, 310.

93 On Roman identity discourse in post-1261 historiography, see Page, Being Byzantine, 102-121, 146-158; cf. Macrides, History, 94.

94 Kyriakidis, Idea of Civil War, 248-254. 
Eastern Roman ethnicity probably played a more important socio-political role in the areas under Turkish and Latin rule. Marino Sanudo wrote in 1330 about the Greeks (i.e. Rhomaioi) living under the Turks in Asia Minor or the Latins in Greece that they were distinguished by their Greek rites and inclination towards the sect of the Greek Church, to which they showed loyalty. ${ }^{95}$ This ethno-cultural demarcation of the Rhomaioi in terms of religious doctrine and language marked their generically subaltern status in the conquered areas but did not make them a priori hostile to the new rulers. The conditions of co-existence with the Turks in Anatolia or the cases of the well-integrated archontes in the Frankish principality of Achaia, as well as of Rhomaioi serving as loyal soldiers under Latin lords, suggest that political loyalty or disloyalty to the new rulers remained primarily a matter of the latter's ability to integrate local identities and interests. ${ }^{96}$

\section{A new vision of ethnogenesis of the Rhomaioi}

The role of political and cultural identifications in the post-1204 Byzantine world provides the point of departure for examining the debated issue of a change in the historical content of Byzantine Romanness. As mentioned above, before 1204 the educated eastern Roman élite propagated a historical identity of the Rhomaioi that went back to ancient Rome, based on the vision of translatio imperii and the relocation of the Roman city-patria from Rome to New Rome. This historical construct of unbroken continuity received a serious blow after the Latin capture of the imperial city, since the new holders of Constantinople claimed imperial Romanness.

This new status quo forced a part of the Byzantine élite to look for an alternative historical source of legitimacy for its Romanness. The self-image of the Rhomaioi as an indigenous collectivity of finite cultural boundaries, which were detached from the boundaries of the Roman imperial politeia and demarcated by the Chalcedonian doctrine and Greek cultural markers, paved the way for a reconstruction of the community's historical past. The educated élite was able to complement the historical scheme of continuity of a people of a political culture bound to a city-state with an image of continuity of a people of historic cultural markers that had diachronically dominated the lands around the Aegean basin, i.e. the current homeland of eastern Roman ethnicity. ${ }^{97} \mathrm{~A}$ latent ideological tendency to identify ethnic Romanness with Hellenic ethno-cultural identity had been underway within certain circles of literati already before $1204 .{ }^{98}$ The emperors of Nicaea John III (1222-1254) and Theodoros II (1254-1258) went a step further and propagated that the Rhomaioi were Hellenes, the descendants of the historical people of the Ancient Greeks. ${ }^{99}$

95 Chroniques gréco-romanes inédites et peu connues, ed. Hopf, 143.

96 Cahen, Pre-Ottoman Turkey, 202-215; Ducellier, Chrétiens d'Orient et islam au moyen âge, 260-275; Balivet, Romanie byzantine et pays de Rûm turc, 30-39, 47-53; idem, Intégration et exclusion,107-124. Jacoby, Encounter of Two Societies, 889-906; Lock, Franks in the Aegean, 284-290. On revolts against Latin rulers, see Nicol, Last Centuries, 185-254; Wright, Byzantine Authority, 253-254.

97 For the notion that the lands around the Aegean basin were the shomeland of Hellenic culture, see Michaelis Pselli oratoria minora, ed. Littlewood, 19, 30-46.

98 Stouraitis, Roman Identity, 210-214.

99 On Hellenic identity in Nicaea, see Koder, Die Hellenis als Mitte der Ökumene, 195-210; Papadopoulou, $P \omega \mu a \tilde{i} о \varsigma$

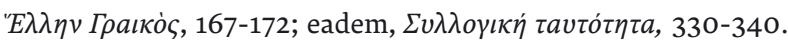


As I have recently argued, this identification indicates a purposeful reconstruction of the community's historical past, inspired by a distinct political goal that had little to do with an ideological or - even less so - political movement of Greek proto-nationalism. ${ }^{100}$ For the Nicaeans, asserting Hellenic ethnicity was interrelated with their claim that the Hellenes were the only rightful heirs to Roman imperial culture, which Constantine I had bestowed upon them through the transfer of the imperial capital from Rome to Constantinople. ${ }^{101}$ The main aim of this claim was to add an ethno-cultural dimension (Latins/Greeks) to the traditional geopolitical vision of translatio imperii from the West to the East. Ethnic Hellenism was emphatically politicized by the Laskarids but not with the intention to marginalize imperial Romanness and the Roman past. Theodore II may have designated the land and the subjects of the Nicaean polity as Hellenic, but the Laskarids equally identified themselves as the only legitimate emperors of the Rhomaioi, their people whose archetypal homeland remained Constantinople. ${ }^{102}$ Hellenic ethnicity and Romanness were not two distinct or, even less so, contrasting identities for the Nicaean élite, but constitutive parts of one and the same identity - that of the contemporary Rhomaioi.

This reconstruction of the historical content of Byzantine Romanness in the successor state whose last ruler Michael VII Palaiologos recaptured Constantinople was conducive for the reinvention of the historical origins of the Rhomaioi in late Byzantium. The Constantinopolitan restoration of 1261 may have fully reinstated Roman imperial ideology and the link to ancient Rome, but did not unmake the Nicaean ideological heritage of convergence between Romanness and ethnic Hellenism. Under emperor Andronikos III Palaiologos (1282-1341), his chief advisor Theodoros Metochites presented the Rhomaioi as partakers and successors of the kinship and the language of the Hellenes, and could address the emperor in a sermon at court as someone that had devoted himself to the salvation of his Hellenic subjects. ${ }^{103}$

There are a number of similar utterances on Hellenic identity by members of the lateByzantine élite, which have been over- or understated within the framework of modern approaches that sought to present the Rhomaioi of late-Byzantium as bearers of an exclusively Greek or Roman national culture, respectively. What both these approaches have in common is the tendency to ignore the malleability of schemes of historical identification in a pre-modern world, where nationalism was not yet the dominant operative ideology of states and societies, in order to dictate a rigid unchangeable view of historical identity. Keeping this in mind, a closer look at the evidence demonstrates that the ideological innovations of the Nicaean court were elaborated in late-Byzantine Constantinople.

In his "Comparison of the Old and the New Rome", addressed to emperor Manuel II Palaiologos (1391-1425), Manuel Chrysoloras presented Rome as the mother and Constantinople as the daughter which was founded by the two most powerful and wise peoples of the world, the Romans and the Hellenes, who had come together there in order to create a city that would be able to rule over the whole world. ${ }^{104}$ In a sermon to the same emperor, he sta-

100 Stouraitis, Roman Identity, 215-218.

101 John III Ducas Vatatzes, Epistula ad Gregorium papam, 18-52, ed. Pieralli, 123-124.

102 On Constantinople as the common patria of the exiled Rhomaioi, see Choniates, Orationes 15, ed. van Dieten, 147, 16-17; John III Ducas Vatatzes, Epistula ad Gregorium papam, 56-11, ed. Pieralli, 125-126. On the use of the ethno-

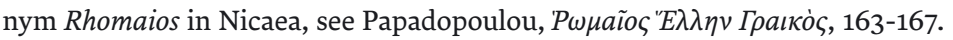

103 Metochites, Miscellanea, 93, 3, ed. Agapitos, Hult and Smith, 38-40; Metochites, Orationes, 2, 8, ed. Polemis, 336, 1-3. 104 Chrysoloras, Comparatio, 33-38, ed. Billò, 16, 12-17, 31. 
ted that the Rhomaioi were the offspring of the Romans and the Hellenes, thus being entitled to use both names. ${ }^{105}$ Such statements delivered to the imperial court testify, in fact, to the crystallization of a new vision of ethnogenesis of the Rhomaioi, in which the Nicaean claim to historical Hellenic ethnicity had merged with the Constantinopolitan claim to an ancestral Roman political culture.

A full-blown version of this new myth of ethnogenesis is found in a sermon held at the court of emperor John VIII Palaiologos (1425-1448) by bishop Isidore of Kiev in $1429^{106}$. Isidore devoted the largest part of the speech to the history of Constantinople, which he presented as the city and patris of the basileus, the reigning metropolis of all cities and the whole Oecumene, and the cradle and mother of the Rhomaioi. ${ }^{107}$ He referred to its foundation and colonization by the Hellenes and its conquest by the Roman imperial power in the course of the subjugation of the whole Oecumene. ${ }^{108}$ From there he went on to praise the perceptiveness of Constantine the Great who had acknowledged the splendour of the location and transferred the imperial power from old Rome to this city, the New Rome. He had brought there "holy relics and unspeakable hoards of treasures and the noblest and bravest among the Romans who he had mingled and united with the noblest of the Hellenes, so that the people of this city became the most distinguished, honourable and noble people of the whole human kind. And this was proper. No other people under the sun was equal to, or greater than, the Hellenes and the Romans, but the one to the other. Thus, it was right and felicitous that the equals were adapted and put together, so that from both these distinguished peoples emerged the most distinguished and honourable of all, which one could rightfully call Rhomellenes «. ${ }^{109}$

This evidence reflects the culmination of an ideological process of reinvention of Roman ethnicity, which had been triggered through the events of 1204 and 1261. By the early-fifteenth century the dominant approach of the members of the late-Byzantine élite to the community's past had amalgamated the Roman and the Hellenic historical heritage, based on the axiom of translatio imperii and the archetypal binding of Roman peoplehood to a city-state. The Rhomaioi of late Byzantium had little interest in their self-imaging as only Roman or only Greek in modern national terms - contrary to some modern historians' eagerness to prove them the one or the other. They rather propagated a historically distinct and unique identity. As their historical homeland, the cradle of their civilization, they regarded neither Ancient Rome nor Ancient Greece but Constantinople, the city where the best from the ancient gene of the Romans and the Hellenes had mingled to give rise to a new people, the Rhomaion genos. This reinvented historical past legitimized them to use the ethnonyms Roman and Hellene interchangeably. Moreover, it represents the ideological background against which the proto-national traits in their identity discourse need to be examined, as a response to a changing world where rhetorical claims to an ecumenical imperial culture made little sense. ${ }^{110}$

105 Chrysoloras, Oratio in imperatorem Manuelem II, 18, 4-18, ed. Patrineles and Sophianos, 117.

106 Schmitt, Kaiserrede, 209-242.

107 Isidore of Kiev, Panegyricus, ed. Lampros 145, 28-30.

108 Isidore of Kiev, Panegyricus, ed. Lampros, 149, 23-151, 29.

109 Isidore of Kiev, Panegyricus, ed. Lampros, 151, 29-152, 17.

110 See Kiousopoulou, Emperor or Manager, 146-150.

medieval worlds $\bullet$ No. $5 \cdot 2017 \cdot 70-94$ 
Among the post-1453 Byzantine historiographers, the author of the Pseudo-Sphrantzes chronicle Makarios Melissenos was the only one to reproduce the late-Byzantine élite's vision of historical identity. In his version of Constantine XI's last speech before the fall, he depicts the emperor as having addressed his audience as the descendants of the Hellenes and the Romans, asking them to defend their patris, Constantinople, the hope and joy of the Hellenes. ${ }^{111}$ In contrast, Michael Doukas was less keen to allude to some glorious ancient past of the Rhomaioi, either Roman or Hellenic, beginning his introductory chronological overview of Roman emperors with Constantine I, whereas in the original chronicle of Georgios Sphrantzes it was neither Roman nor Hellenic, but only Christian identity that mattered. ${ }^{112}$ At the other end, Laonikos Chalkokondyles, influenced by his master George Plethon Gemistos, ${ }^{113}$ was keen to fully erase the ethnonym Rhomaios from the historical record by referring to the Constantinopolitan Empire as the Empire of the Hellenes. ${ }^{114}$

These different approaches are a good reminder of the medieval historian's arbitrary prerogative to construct or reinvent the historical past according to his/her patron's or circle's political concerns and ideological priorities, respectively. When these histories were written, the Rhomaioi had sunk in the melting pot of the Ottoman Empire as an ethno-cultural category of Greek-speaking Christians. Their popular historical memory was marked neither by the glories of Ancient Rome nor by whitewashed Hellenism, but by legends that lamented the loss of the Christian homeland, Constantinople, and highlighted the myth of its last emperor, prophesizing his return for the reconquest of the city in times to come. ${ }^{115}$

\section{Acknowledgements}

This paper presents results of the research project »Ideologies under scrutiny: Differentiated perceptions of Roman imperial ideals in Byzantine society (7th-12th c.)«(P 24752-G19), funded by the Austrian Science Fund (FWF).

111 Pseudo-Sphrantzes, Chronicon sive Maius, ed. Grecu, 414, 21-420, 33.

112 On a detailed examination of these historians' different approaches, see Smarnakis, Rethinking Roman Identity, passim.

113 George Plethon Gemistos was the main representative of a diverging strand of thought in late Byzantium. His outline of a political program for the creation of a Hellenic ethnic kingdom in the Peloponnese indicates a genuine vision of Hellenic proto-nationalism; cf. Woodhouse, George Gemistos Plethon, 102-109; Siniossoglou, Radical Platonism, 327-359.

114 Laonikos Chalkokondyles, Historiae, ed. Darkó, I 1-7. Cf. Kaldellis, New Herodotos, 216-228.

115 Nicol, Immortal Emperor, 88-108; Papayianni, He Polis healo, 37-42. 


\section{References}

\section{Primary Sources}

Anastasios the Persian, Life and Miracles, ed. Bernard Flusin, Saint Anastase le Perse et l'histoire de la Palestine au début du VIIe siècle, vol. 1 (Paris, 1992).

Anna Komnene, Alexias, eds. Dieter R. Reinsch and Athanasios Kambylis, Anna Comnenae Alexias (CFHB XL/1) (Berlin, 2001).

Arethae Archiepiscopi Caesariaensis Scripta Minora II, ed. Leendert G. Westerink (Leipzig, 1968).

Attaleiates, Historia, ed. Inmaculada Pérez Martín, Miguel Ataliates, Historia (Madrid, 2002)

Basilicorum Libri LX, series A, vol. I, textus librorum I-VIII, ed. Herman J. Scheltema (Croningen, 1955).

Cantacuzenus, Historiae, ed. Ludwig Schopen, Ioannis Cantacuzeni eximperatoris historiarum libri iv, vol. 1 (CSHB) (Bonn, 1828).

Choniates, Historia, ed. J van Dieten, Nicetae Choniatae historia, pars prior (CFHB 11.1) (Berlin, 1975).

Chronicon Toccorum, ed. Giuseppe Schirò, Cronaca dei Tocco di Cefalonia (CFHB 10) (Rome, 1975).

Chroniques gréco-romanes inédites et peu connues, ed. Carl Hopf (Berlin, 1873).

De administrando imperio, ed. Gyula Moravcsik, trans. Romily J. H. Jenkins, Constantine Porphyrogennitus De administrando imperio (CFHB 1) (Washington, D.C., 1967).

De re military, ed. George T. Dennis, Three Byzantine Military Treatises (Washington, D.C., 1985).

De thematibus, ed. Agostino Pertusi, Costantino Porfirogenito De thematibus (Vatican City, 1952).

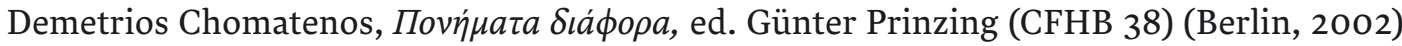

Docrtina Jacobi nuper Baptizati, éd. et trad. Vincent Déroche, Travaux et Mémoires 11 (1991) 47-229.

Eunapius, Fragmenta historica, ed. L. Dindorf, Historici Graeci minores, vol. 1 (Leipzig, 1870). English Translation: R. C. Blockley, The Fragmentray Classicizing Historians of the Later Roman Empire: Eunapius, Olympiodorus, Priscus and Malchus, vol. 2: Text, Translation and Historiographical Notes (Wiltshire, 1983).

Evodius, Vita martyrum XLII Amoriensum, ed. Petr Vasil'evč Nikitin and Vasilij Grigorévič Vasilievskij, Skazanija o 42 amorijskich mucenikach (St. Petersburg, 1906) 61-78.

George Bardanes, Epistula ad Germanum II, ed. Raymond-Joseph Loenertz, Lettre de Georges Bardanès, métropolite de Corcyre, au patriarche oecuménique Germain II 1226-1227 c.,

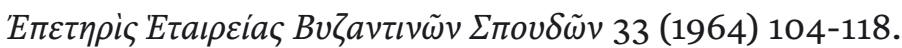

Isidor of Kiev, Panegyricus ad Manuelem et Joannem VIII Palaeologum, ed. Spyridon P. Lamp-

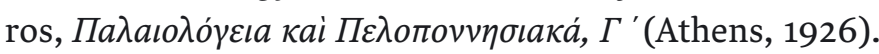

John III Ducas Vatatzes, Epistula ad Gregorium papam, ed. Luca Pieralli, La corrispondenza diplomatica dell'imperatore Bizantino con le potenze estere nel tredicesimo secolo (1204-1282). Studio storico-diplomatice et edizione critica (Cità del Vaticano, 2006) 119-126.

Kekaumenos, Consilia et Narrationes, ed. Charlotte Rouché. Retrieved on 10 March 2017 from the Sharing Ancient Wisdoms project: http://www.ancientwisdoms.ac.uk/library/kekaumenos-consilia-et-narrationes/.

Kinnamos, Epitome, ed. A. Meineke, Epitome rerum ab Ioanne et Alexio Comnenis gestarum, (CSHB) (Bonn, 1836). 
Laonikos Chalkokondyles, Historiae, ed. Eugenius Darkó, Laonici Chalcocandylae historiarum demonstrationes, 2 vols. (Budapest, 1922-1923).

Legatio Liutprandi Cremonensis Episcopi ad Imperatorem Constantinopolitanum Necephroum Phocam pro Ottonibus Augustis et Adelheida, ed. Paolo Chiesa, Liutprandi Cremonensis Opera Omnia (Turholt, 1998).

Leo the Deacon, Historia, ed. Charles-Benoît Hase, Leonis diaconi Caloënsis historiae libri decem (CSHB) (Bonn 1828); Talbot, Mary-Alice and Sullivan Dennis F., The History of Leo the Deacon: Byzantine Military Expansion in the Tenth Century (Washington, D.C., 2005).

Leonis VI Tactica, ed. George D. Dennis, The Taktika of Leo VI. Text, Translation and Commentary (CFHB XLIX) (Washington, D.C., 2010).

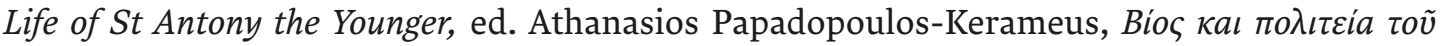

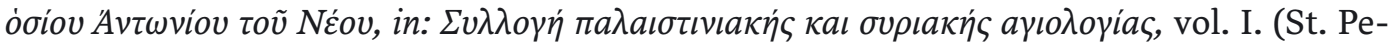
tersburg, 1907).

Manuel Chrysoloras, Comparatio veteris et novae Romae, ed. Cristina Billò, Manuele Crisolora, Confronto tra l'Antica e la Nuova Roma, Medioevo Greco »0« (2000) 1-26

Manuel Chrysoloras, Oratio in imperatorem Manuelem II Palaeologum, ed. Chrestos G. Patrineles and Demetrios Z. Sophianos, Manuel Chrysoloras and his Discourse Addressed to the Emperor Manuel II Palaeologus (Athens, 2001).

Michael Choniates, Epistulae, ed. Foteini Kolobou, Michaelis Choniatae epistulae (CFHB 41) (Berlin, 2001).

Michael Syncellus, Encomium martyrum XLII Amoriensum (versio $\Gamma$ ), ed. P. Nikitin and V. Vasilievskij, Skazanija o 42 amorijskich mucenikach (St. Petersburg, 1906).

Michaelis Pselli oratoria minora, ed. A.R. Littlewood (Leipzig, 1985).

Nicephoros Blemmydes, Curriculum vitae, ed. A. Munitiz, Nicephori Blemmydae Autobiographia sive Curriculum Vitae necnon Epistula Universalior (Turnhout, 1984)

Nikolaos I Mystikos, Epistulae, ed. Romily James Heald Jenkins and Leendert Gerrit Westerink, Nicholas I, Patriarch of Constantinople, Letters (CFHB 6) (Washington, D.C., 1973).

Pachymeres, Historiae, ed. Albert Failler and Vitalien Laurent, Georges Pachymérès. Relations historiques, 2 vols. (CFHB 24, 1-2) (Paris, 1984).

Pseudo-Sprhantzes (Makarios Melissenos), Chronicon sive Maius, ed. Vasile Grecu, Georgios Sphrantzes. Memorii 1401-1477 (Scriptores Byzantini 5) (Bucharest, 1966).

Skylitzes, Synopsis, ed. Johannes Thurn, Ioannis Scylitzae synopsis historiarum (CFHB 5) (Berlin, 1973).

Theodoros Metochites, Miscellanea philosophica et historica, ed. Panagiotis A. Agapitos, Karin Hult, and Ole L. Smith, Theodorus Metochites on Philosophic Irony and Greek History: Miscellanea 8 and 93 (Nicosia, 1996).

Theodoros Metochites, Orationes in imperatorem Andronicum II, ed. Ioannis Polemis, Oi $\Delta$ v́o

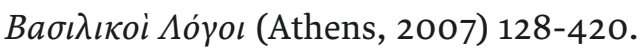

Theophanes Continuatus (liber VI), ed. Immanuel Bekker (Bonn, 1838).

Theophanes Continuatus (libri I-IV), ed. Michael Featherstone and Juan Signes Codoñer, Chronographiae quae Theophanis Continuati nomine fertur Libri I-IV (CFHB 53) (Berlin, 2015).

Theophanes, Chronographia, ed. Carl De Boor (CSHB) (Leipzig, 1883); transl. with introduction and commentary by Mango, and Scott Roger, The Chronicle of Theophanes Confessor: Byzantine and Near Eastern History, AD 284-813 (Oxford, 1997).

Vasilievsky, Vasili, Epirotica saeculi XIII, Vizantijski Vremennik 3 (1896) 233-316. 
Vita Basilii, ed. Ihor Ševčenko, Chronograpiae quae Theophanis Continuati nomine fertur. Liber quo Vita Basilii Imperatoris ampelicitur (CFHB XLII) (Berlin, 2011).

Vita Clementis Ochridensis, in: A. Milev, Gruckite zitija na Kliment Ochridski (Sofia, 1966).

Zonaras, Epitome, ed. Ludwig August Dindorf, Ioannis Zonarae epitome historiarum, vol. I (Leipzig, 1868).

\section{Secondary Literature}

Ahrweiler, Hélène, L'idéologie politique de l'Empire byzantin (Paris, 1975).

Anderson, Benedict, Imagined Communities: Reflections on the Origin and Spread of Nationalism (London, 2006).

Balivet, Michel, Intégration et exclusion des chrétiens dans le sultanat seldjoukide d'AsieMineure (XIIe-XIIIe s.), in M. Balivet (ed.), Mélanges byzantins, seldjoukides et ottomans (Istanbul, 2005).

Balivet, Michel, Romanie byzantine et pays de Rûm turc: Histoire d'un espace d'imbrication gréco-turque, (Les Cahiers du Bosphore 10) (Istanbul, 1994).

Beaton, Roderick, Antique Nation? >Hellenes on the Eve of Greek Independence and in Twelfth Century Byzantium, Byzantine and Modern Greek Studies 31 (2007) 76-95.

Billig, Michael, Banal Nationalism (London, 1995).

Browning, Robert, Greeks and Others: From Antiquity to the Renaissance, in: Robert Browning, History, Language and Literacy in the Byzantine World (Northampton, 1989) 1-26.

Brubaker, Leslie and Haldon, John, Byzantium in the Iconoclast Era, c. 680-850: a History (Cambridge, 2011).

Brubaker, Rogers and Cooper, Frederick, Beyond sIdentity<, Theory and Society 29 (2000) 1-47.

Brubaker, Rogers, Ethnicity without Groups (Cambridge, Mass., 2004).

Brubaker, Rogers, Rethinking Nationhood, Contention 4/1 (1994) 3-14.

Cahen, Claude, Pre-Ottoman Turkey: A General Survey of the Material and Spiritual Culture and History, c. 1071-1330 (New York, 1968).

Cheynet, Jean-Claude, L'apport arabe à l'aristocratie byzantine des IXe-Xe siècles, Byzantinoslavica 56 (1995) 137-146.

Cheynet, Jean-Claude, Pouvoir et contestation à Byzance (963-1210) (Paris, 1990).

Croke, Brian, Uncovering Byzantium's Historiographical Audience, in: Ruth Macrides (ed.), History as Literature in Byzantium, Papers from the Fortieth Spring Symposium of Byzantine Studies, University of Birmingham, April 2007 (Farnham, 2010) 25-53.

Curta, Florin, Burial in Early Medieval Greece: on Ethnicity in Byzantine Archaeology, in: Studia in Honorem Professoris Borisi Borisov (Veliko Tarnovo, 2016) 419-448.

Ditten, Hans, Ethnische Verschiebungen zwischen der Balkanhalbinsel und Kleinasien vom Ende des 6. bis zur zweiten Hälfte des 9. Jahrhunderts (Berlin, 1993).

Ducellier, Alain, Chrétiens d'Orient et islam au moyen âge, VIIe-XVe siècle (Paris, 1996).

Fatouros, Georgios und Krischer, Tilman, Johannes Kantakuzenos Geschichte II (Stuttgart, 1986).

Garsoïan, Nina G., The Problem of Armenian Integration into the Byzantine Empire, in: Hélène Ahrweiler and Angeliki E. Laiou (eds.), Studies on the Internal Diaspora of the Byzantine Empire (Washington., D.C., 1998).

Haldon, John, Res publica Byzantina? State Formation and Issues of Identity in Medieval East Rome, Byzantine and Modern Greek Studies 40/1 (2016) 4-16. 
Haldon, John, The Empire that Would Not Die: the Paradox of Eastern Roman Survival, 640-740 (Cambridge, Mass., 2016).

Hobsbawm, Eric J., Nations and Nationalism since 1780: Programme, Myth, Reality (Cambridge, 1990).

Hoffmann, Jürgen, Rudimente von Territorialstaaten im Byzantinischen Reich (1071-1210) (Munich, 1974).

Ichijo, Atsuko and Uzelac, Gordana (eds.), When is the Nation? Towards an Understanding ofTtheories of Nationalism (New York, 2005).

Jacoby, David, The Encounter of Two Societies: Western Conquerors and Byzantines in the Peloponnesus after the Fourth Crusade, The American Historical Review 78/4 (1973) 873906.

Jenkins, Richard, Rethinking Ethnicity (second edition) (London 2008).

Kaldellis, Anthony, A New Herodotos: Laonikos Chalkokondyles on the Ottoman Empire, the Fall of Byzantium, and the Emergence of the West (Washington, D.C., 2014).

Kaldellis, Anthony, From Rome to New Rome, from Empire to Nation-State: Reopening the Question of Byzantium's Roman Identity, in: Lucy Grig and Gavin Kelly (eds.), Two Romes: Rome and Constantinople in Late Antiquity (Oxford, 2012) 387-404.

Kaldellis, Anthony, Hellenism in Byzantium: the Transformations of Greek Identity and the Reception of the Classical Tradition (Cambridge, 2007).

Kaldellis, Anthony, The Byzantine Republic: People and Power in New Rome (Cambridge, MA, 2015).

Kiousopoulou, Tonia, Emperor or Manager: Power and Political Ideology in Byzantium before 1453 (Geneva, 2011).

Koder, Johannes, Byzantium as Seen by Itself - Images and Mechanisms at Work, in: Proceedings of the 22nd International Congress of Byzantine Studies Sofia, 22-27 August 2011, I. Plenary Papers (Sofia, 2011) 69-81.

Koder, Johannes, Die Hellenis als Mitte der Ökumene: Theodoros Laskaris über den Ursprung von Philosophie, Weisheit und Wissenschaft, in: Theodora Antonopoulou, Sofia Kotzabassi and Marina Loukaki (eds.), Myriobiblos: Essays on Byzantine Literature and Culture (Athens, 2016) 195-210.

Koder, Johannes, Sprache als Identitätsmerkmal bei den Byzantinern (Auf -isti endende sprachenbezogene Adverbien in den griechischen Quellen), Anzeiger der philosophischhistorischen Klasse der Österreichischen Akademie der Wissenschaften 147 (2012) 5-37

Kumar, Krishan, Nation-states as Empires, Empires as Nation-States: Two Principles, One Practice?, Theory and Society 39/2 (2010) 119-143.

Kyriakidis, Savvas, Warfare in Late Byzantium, 1204-1453 (Leiden, 2011).

Kyriakidis, The Idea of Civil War in Thirteenth and Fourteenth-Century Byzantium, Zbornik Radova Vizantološkog Instituta 49 (2012) 243-256.

Lilie, Ralph-Johannes, Des Kaisers Macht und Ohnmacht. Zum Zerfall der Zentralgewalt in Byzanz vor dem vierten Kreuzzug, in: Poikila Byzantina 4, Varia I: Beiträge von R.-J. Lilie und P. Speck (Bonn, 1984) 9-120.

Lilie, Ralph-Johannes, Die byzantinische Gesellschaft im Spiegel ihrer Quellen, Zbornik radova Vizantološkog instituta 50 (2013) 959-968.

Lilie, Ralph-Johannes, Reality and Invention: Reflections on Byzantine Historiography, Dumbarton Oaks Papers 68 (2014) 157-210.

Lilie, Ralph-Johannes, Zur Stellung von ethnischen und religiösen Minderheiten in Byzanz: Armenier, Muslime und Paulikianer, in: Walter Pohl, Clemens Gantner andRichard Payne 
(eds.), Visions of Community in the Post-Roman World: the West, Byzantium and the Islamic world, 300-1100 (Farnham, 2012) 301-316.

Lock, Peter, The Franks in the Aegean, 1204-1500 (London, 1995).

Macrides, Ruth, George Akropolites: The History. Introduction, Translation and Commentary (Oxford, 2007).

Magdalino, Paul, Constantine VII and the Historical Geography of Empire, in Sahar Bazzaz, Yota Batsaki and Dimiter Angelov (eds.), Imperial Geographies in Byzantine and Ottoman Space (Cambridge, Mass. 2013) 23-41.

Malatras, Christos, The Making of an Ethnic Group: The Romaioi in the 12th-13th Centuries, in: Konstantinos A. Dimadis (ed.), Identities in the Greek World (From 1204 to the Present Day), Proceedings of the 4th European Congress of Modern Greek Studies Granada, 9-12 September 2010 (Athens, 2011) 419-430.

Malešević, Siniša, "Divine Ethnies" and "Sacred Nations«: Anthony D. Smith and the Neo-Durkhemian Theory of Nationalism, Nationalism and Ethnic Politics 10 (2004) 561593

Malešević, Siniša, Identity as Ideology: Understanding Ethnicity and Nationalism (Basingstoke, 2006).

Malešević, Siniša, Nation-States and Nationalisms: Organization, Ideology and Solidarity (Cambridge, 2013).

Markopoulos, Athanasios, Roman Antiquarianism: Aspects of the Roman Past in the Middle Byzantine Period (9th-11th Centuries), Proceedings of the 21st International Congress of Byzantine Studies, London 21-26 August, 2006, Plenary Papers, 1 (Aldershot, 2006) 277-297.

Nicol, David M., The Immortal Emperor: the Life and Legend of Constantine Palaiologos, Last Emperor of the Romans (Cambridge, 1992).

Nicol, David, The Last Centuries of Byzantium, 1261-1453 (Cambridge 1994).

Page, Gill, Being Byzantine: Greek Identity before the Ottomans (Cambridge, 2008).

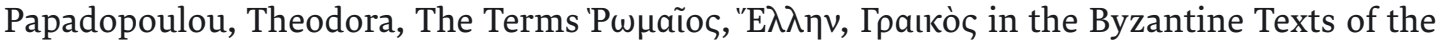
first half of the 13th century, Byzantina Symmeikta 24 (2014) 157-17.

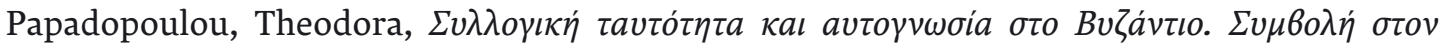

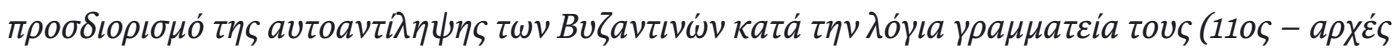
$130 v$ al.) (Athens, 2015).

Papayianni, Aphrodite, He Polis healo: the Fall of Constantinople in 1453 in Post-Byzantine Popular Literature, Al Masaq 22/1 (2010) 27-44.

Rapp, Claudia, Hellenic Identity, Romanitas, and Christianity in Byzantium, in: Katerina Zacharia (ed.), Hellenisms. Culture, Identity and Ethnicity from Antiquity to Modernity (Aldershot, 2008) 127-147.

Schmitt, Oliver J., Kaiserrede und Zeitgeschichte im späten Byzanz: ein Panegyrikos Isidors von Kiev aus dem Jahre 1429, Jahrbuch der Österreichischen Byzantinistik 48 (1998) 209242.

Siniossoglou, Niketas, Radical Platonism in Byzantium: Illumination and Utopia in Gemistos Plethon (Cambridge, 2011).

Smarnakis, Ioannis, Rethinking Roman Identity after the Fall (1453): Perceptions of $>$ Romanitas by Doukas and Sphrantzes, Byzantina Symmeikta 25 (2015) 211-234.

Smith, Anthony D., Ethno-Symbolism and Nationalism: a Cultural Approach (London, 2009).

Smith, Anthony D., National Identity (London, 1991).

Smith, Anthony D., Nationalism and Modernism: a Critical Survey of Recent Theories of Nations and Nationalism (London, 1998). 
Smith, Anthony D., The Cultural Foundations of Nations: Hierarchy, Covenant, and Republic (Malden, MA, 2008).

Stephenson, Paul, Byzantium's Balkan Frontier: a Political Study of the Northern Balkans, 90o1204, Cambridge 2000.

Smith, Anthony D., Book Review: Azar Gat with Alexander Yakobson, Nations: The Long History of Deep Roots of Political Ethnicity and Nationhood, Nations and Nationalism 19/4 (2013) 819-834.

Sode, Claudia, Untersuchungen zu De administrando imperio Kaiser Konstantins VII. Porphyrogenitus, Poikila Byzantina 13 (Bonn, 1994) 149-260.

Stouraitis, Ioannis, Just War and >Holy War in the Middle Ages: Rethinking Theory through the Byzantine Case-Study, Jahrbuch der Österreichischen Byzantinistik 62 (2012) 227-264.

Stouraitis, Ioannis, Krieg und Frieden in der politischen und ideologischen Wahrnehmung in Byzanz (7. - 11. Jahrhundert) (Vienna, 2009).

Stouraitis, Ioannis, Roman Identity in Byzantium: a Critical Approach, Byzantinische Zeitschrift 107/1 (2014) 175-220.

Stouraitis, Yannis, Book Review: Kaldellis, Anthony, The Byzantine Republic: People and Power in New Rome, Journal of Hellenic Studies 136 (2016), 296-297.

Woodhouse, Christopher M., George Gemistos Plethon: The Last of the Hellenes (Oxford 1986). Wright, Chris, Byzantine Authority and Latin Rule in the Gattilusio Lordships, in: Jonathan Harris, Cathrine Holmes and Eugenia Russell (eds.), Byzantines, Latins, and Turks in the Eastern Mediterranean World after 1150 (Oxford, 2012) 247-263. 